\title{
Culturable diazotrophic bacterial community associated with Agave sisalana P. plants from semi-arid regions in Brazil
}

\author{
Adailson Feitoza de Jesus Santos ${ }^{1} \oplus$, Zayda Piedad Morales Moreira² ${ }^{\oplus}$, Jorge Teodoro de Souza ${ }^{3} \oplus$, \\ Lenaldo Muniz de Oliveira ${ }^{4} \oplus$, Heloiza Ramos Barbosa ${ }^{5} \bullet$, Eliane de Souza Silva ${ }^{6}$, \\ Rafael Mota da Silva ${ }^{7}$, Ana Cristina Fermino Soares ${ }^{6}[0$ \\ ${ }^{1}$ Universidade do Estado da Bahia, Departamento de Tecnologia e Ciências Sociais, Juazeiro, BA, Brazil. E-mail: adailsonmicrobiologia@gmail.com \\ 2 University of Saskatchewan, College of Agriculture and Bioresources, Department of Food and Bioproduct Sciences, Saskatoon, SK, Canada. E-mail: z.morales@usask.ca \\ ${ }^{3}$ Universidade Federal de Lavras, Departamento de Fitopatologia, Lavras, MG, Brazil. E-mail: jgeteodoro@gmail.com \\ ${ }^{4}$ Universidade de Feira de Santana, Horto Florestal, Laboratório de Cultura de Tecidos Vegetais, Feira de Santana, BA, Brazil. E-mail: lenaldo.uefs@gmail.com \\ ${ }^{5}$ Universidade de São Paulo, Instituto de Ciências Biomédicas, Departamento de Microbiologia, São Paulo, SP, Brazil. E-mail: hrbarbos@icb.usp.br \\ ${ }^{6}$ Universidade Federal do Recôncavo da Bahia, Centro de Ciências Agrárias, Ambientais e Biológicas, Laboratório de Microbiologia Agrícola, Cruz das Almas, BA, Brazil. E-mail: \\ any.biologia@hotmail.com; ferminosoares@gmail.com \\ ${ }^{7}$ Faculdade da Região Sisaleira, Conceição do Coité, BA, Brazil. E-mail: rafaelmotasilva@hotmail.com
}

ABSTRACT: The aim of this study was to isolate, quantify, identify and characterize the culturable diazotrophic bacterial community associated with sisal (Agave sisalana P.) and assess its potential for plant growth promotion and tolerance to abiotic stress. Nitrogen-free Burk's medium was used for bacteria isolation and quantification. Isolates carrying the nifH gene were typed by BOX-PCR and sequenced for the $16 \mathrm{~S}$ rRNA region. Additionally, the bacteria was tested for growth promotion in maize plants and for salinity tolerance in cucumber seedlings. The representative isolates were identified as members of Pantoea, Rhizobium, Burkholderia, Leifsonia and Bacillus genera. All isolates were positive for at least two of the nine plant growth promoting (PGP) traits tested. All isolates showed positive traits for tolerance to abiotic stress. Leifsonia sp. (S1.5) significantly increased root length, stem length and total fresh matter, and it was involved in the reduction of deleterious salt effects $(60 \mathrm{mM} \mathrm{NaCl})$ in cucumber seedlings. Diazotrophic bacterial community associated with sisal plants is genetically diverse, exhibits several plant growth-promoting traits and shows potential to support plant growth in adverse environments (salinity).

Key words: abiotic stress; PGPB; rhizospheric bacteria

\section{Comunidade bacteriana diazotrófica cultivável associada com Agave sisalana P. de regiões semi-áridas do Brasil}

RESUMO: O objetivo deste estudo foi isolar, quantificar, identificar e caracterizar a comunidade bacteriana diazotrófica cultivável associada com sisal (Agave sisalana P.) e avaliar o seu potencial para promoção de crescimento vegetal e tolerância a estresse abiótico. Para isolamento e quantificação das bactérias foi utilizado o meio de cultura Burk's livre de nitrogênio. Isolados contendo o gene nifH foram caracterizados usando BOX-PCR e em seguida a região $16 \mathrm{~S}$ rRNA foi sequenciada. As bactérias foram testadas para promoção de crescimento em plantas de milho e para indução de tolerância a salinidade em mudas de pepino. Os isolados representativos foram identificados como membros dos gêneros Pantoea, Rhizobium, Burkholderia, Leifsonia e Bacillus. Todos os isolados foram positivos para pelo menos duas das nove caractetísticas de promoção de crescimento vegetal (PCV) testadas. Todos os isolados apresentaram características positivas para tolerância a estresse abiótico. Leifsonia sp. (S1.5) aumentou significativamente o comprimento da raíz, caule e matéria fresca total e reduziu os efeitos deletérios do sal $(60 \mathrm{mM})$ nas mudas de pepino. A comunidade bacteriana diazotrófica associada com plantas de sisal é geneticamente diversa, possui diversas características para promoção de crescimento e apresenta potencial para manter o cresicmento de plantas em condições adversas (salinidade).

Palavras-chave: estresse abitótico; BPCP; bactéria rizosférica 


\section{Introduction}

The Northeast region of Brazil has an extensive area with a semi-arid climate with average rainfall ranging from 400 to $800 \mathrm{~mm}$ (Rodal et al., 2018). The vegetation is composed of small trees, plants belonging to Cactaceae family, and perennial shrubs with spines, most of them deciduous in the dry season (Queiroz, 2006).

Sisal (Agave sisalana Perrine) is an Asparagaceae introduced from Mexico that has been grown for hard fiber production in large areas of the Northeastern semi-arid region of Brazil (Suinaga et al., 2006), being the main commercial crop for local farmers. The Northeast is the only Brazilian region where sisal is commercially produced, and the state of Bahia is responsible for approximately $95 \%$ of the national production with 197.748 hectares of harvested area (IBGE, 2017).

Microorganisms associated with plants from arid and semi-arid region exhibit some traits that help them to survive and thrive under harsh climatic conditions. Native vegetation, as well as sisal plants, host a bacterial community which has been of special interest for researchers in recent years due to its role in plant growth promotion and tolerance to abiotic stress (Santos et al., 2014; Lima et al., 2015). Several studies have shown that microorganisms adapted to these regions can enhance the tolerance of plants to abiotic stress, such as high salt concentrations (Navarro-Torre et al., 2017). For example, AKM-P6, a thermotolerant Pseudomonas sp. strain leads to an increase in tolerance to high temperatures in sorghum seedlings. Inoculation of seedlings induced the biosynthesis of high molecular weight molecules in leaves under high temperatures, reducing cell membranes injuries and increasing cell metabolites levels, such as: chlorophyll, proline, sugars, amino acids and proteins (Ali et al., 2009). Thus, bacterial communities produce substances that not only play a role in their survival, but also induce plants to synthesize compounds involved in their adaptation to adverse environmental conditions.

Plant tolerance to arid and semi-arid environments could be improved by rhizospheric and endophytic microorganisms, known as plant growth promoting bacteria (PGPB) (Naveed et al., 2014; Timmusk et al., 2014). PGPB may indirectly or directly promote plant growth and development. Direct promotion of plant growth commonly involves mechanisms that allow the acquisition of nutrients from the environment, including nitrogen fixation, iron sequestration by bacterial siderophores, phosphate solubilization and the alteration of plant hormone levels such as cytokinin, auxin and ethylene. Indirect plant growth promotion occurs by a decrease or prevention of deleterious effects caused by plant pathogens (Gamalero \& Glick, 2015) or by abiotic stress through different mechanisms (Naveed et al., 2014). For instance, nitrogenfixing bacteria can play an important role since sisal has been grown in Brazil for many decades without any nitrogen fertilization (Santos et al., 2014).
The aim of this study was to isolate, quantify, identify and characterize diazotrophic bacteria associated with sisal in a semiarid region in Bahia, Brazil. Additionally, their potential to promote plant growth and role in abiotic stress tolerance were assessed for future applications in sisal or other crops grown in semi-arid environments.

\section{Material and Methods}

\section{Sampling area}

Sisal plants and rhizosphere soil were collected in a production area located in the municipality of Conceição do Coité (11 31 '18.4" S; 39 16' 09.4" W), Bahia State, Brazil. The local climate is characterized by high potential evapotranspiration (2,000 $\mathrm{mm}$ per year), an average rainfall of $700 \mathrm{~mm}$ per year (minimum 300 and maximum 1,000 $\mathrm{mm}$ ) during three to five months a year and temperatures ranging from 23 to $27^{\circ} \mathrm{C}$. The vegetation found in the region is characterized as open Caatinga without palm trees.

\section{Bacterial quantification and isolation}

Five samples of sisal rhizosphere, roots, stems, leaves, stalks, and bulbils were randomly collected and immediately transported to the laboratory in Styrofoam boxes. Ten grams of rhizosphere samples were added to $90 \mathrm{~mL}$ of saline solution $(\mathrm{NaCl} 0.85 \%)$ and serial dilutions were carried out. Samples containing $10 \mathrm{~g}$ of each plant tissue were surface sterilized (alcohol at $70 \%$ for $1 \mathrm{~min}, \mathrm{NaOCl}$ at $1 \%$ for $3 \mathrm{~min}$, and three successive rinses with sterile distilled water), grounded in a mortar, and serially diluted in saline solution (0.85\%). For the diazotrophic bacterial community isolation, aliquots of $100 \mu \mathrm{L}$ from $10^{-2}$ to $10^{-4}$ dilutions of all samples, including soil and surface-sterilized plant tissues, were spread in triplicate into tubes containing Burk's semi-solid nitrogen free selective medium ( $\mathrm{g} \mathrm{L}^{-1}: 10 \mathrm{~g}$ of glucose, $0.41 \mathrm{~g}$ of $\mathrm{KH}_{2} \mathrm{PO}_{4}, 0.52 \mathrm{~g}$ of $\mathrm{K}_{2} \mathrm{HPO}_{4}, 0.05 \mathrm{~g}$ of $\mathrm{Na}_{2} \mathrm{SO}_{4}, 0.2 \mathrm{~g}$ of $\mathrm{CaCl}_{2} ; 0.1 \mathrm{~g}$ of $\mathrm{MgSO}_{4} .7 \mathrm{H}_{2} \mathrm{O}$, $0.005 \mathrm{~g}$ of $\mathrm{FeSO}_{4} .7 \mathrm{H}_{2} \mathrm{O}, 0.0025 \mathrm{~g}$ of $\mathrm{Na}_{2} \mathrm{MoO}_{4} .2 \mathrm{H}_{2} \mathrm{O}, 1.8 \mathrm{~g}$ of agar, with $\mathrm{pH}$ adjusted to 7.0) (Wilson \& Knight, 1952) and incubated at 28 으 during 7 days. In order to confirm the disinfection protocol, aliquots of sterile water used in the final rinse were plated on 10\% TSA (Tryptic Soy Agar) and incubated at 28 o $C$ during $48 \mathrm{~h}$.

Bacterial quantification was performed using the most probable number (MPN) method. Aliquots of $50 \mu \mathrm{L}$ of the growth subsurface pellicle were transferred to Petri dishes containing solid Burk's medium and incubated at $28{ }^{\circ} \mathrm{C}$ for 7 days. Morphologically distinct colonies were picked and purified in solid Burk's medium and incubated at $28{ }^{\circ} \mathrm{C}$ for 7 days. Individual colonies were stored at -80 ㅇ $\mathrm{C}$ in $40 \%$ glycerol and TSB (Tryptic Soy Broth) for further experiments.

Presence of the nifH gene, diversity, and molecular identification

DNA extraction and amplification were performed as previously described by Santos et al. (2014). Fragments of the nifH gene were amplified by nested PCR in two steps: 1) a 
reaction with primers PolF - (5'-TGCGAYCCSAARGCBGACTC-3') and PoIR - (5'-ATSGCCATCATYTCRCCGGA-3') that target a 360-bp fragment of this gene from a wide range of diazotrophic microorganisms; 2 ) a reaction with the product amplified in the first step using the pair of primers nifHFor (5'-ACCCGCCTGATCCTGCACGCCAAGG-3') and nifHRev (5'-ACGATGTAGATTTCCTGGGCCTTGTT-3') that amplify a 314 -317-bp fragment.

Isolates carrying the nifH gene were typing by BOX-PCR $A 1-R$ to assess the genomic diversity of the diazotrophic bacterial community, according to Santos et al. (2014). The banding patterns on the gel were converted into a binary matrix. The similarity matrix was calculated using the Jaccard's coefficient (Legendre \& Legendre, 1983) and the dendrogram was obtained with the UPGMA algorithm using the software FreeTree version 0.9.1.50.

16S rRNA gene was amplified from DNA samples by PCR using 27F (5'-AGAGTTTGATCMTGGCTCAG) and 1492R (5'-TACGGYTACCTTGTTACGACTT) primers (with expected amplicon size of $1465 \mathrm{bp})$. Each PCR reaction was carried out according to Weisburg et al. (1991). PCR products were sequenced by Macrogen (Seoul, South Korea) using a $3730 x /$ sequencer (Applied Biosystems, Drive Foster City, CA, USA). Sequences were analyzed using the Sequence Scanner Software v. 2.0 (Applied Biosystems) and the contigs assembled using the BioEdit software v 7.0 (http://mbio. ncsu.edu/BioEdit/bioedit.html). Sequences were deposited in GenBank, a database of the National Center for Biotechnology Information (http://www.ncbi.nlm.nih.gov/Genbank) under the accession numbers KR094730 to KR094773 (Fig 2). Bacterial identification at the genus level was performed with BLAST searches (Altschul et al., 1990) in public databases. Sequence alignment, model selection and tree reconstruction were performed using the software Mega version 5.2.1 (Tamura et al., 2011).

EPS production, drought, salinity and temperature tolerance

Exopolysaccharide (EPS) production was measured as described by Paulo et al. (2012). The tested isolates were inoculated into sterilized filter paper discs of $5 \mathrm{~mm} \varnothing$ placed on the surface of culture medium modified by Guimarães et al. (1999) containing (2\% yeast extract, $1.5 \% \mathrm{~K}_{2} \mathrm{HPO}_{4}, 0.02 \%$ $\mathrm{MgSO}_{4}, 0.0015 \% \mathrm{MnSO}_{4}, 0.0015 \% \mathrm{FeSO}_{4}, 0.003 \% \mathrm{CaCl}_{2}$, $0.0015 \% \mathrm{NaCl}, 1.5 \%$ agar and $10 \%$ sucrose, with $\mathrm{pH}$ adjusted to 7.5) followed by incubation at $30^{\circ} \mathrm{C}$ for $48 \mathrm{~h}$. A mucoid layer formed around the paper discs suggested EPS production. In order to confirm the presence of EPS, the mucoid layer was transferred to a tube containing $2 \mathrm{~mL}$ absolute ethanol. The EPS presence was confirmed by the formation of a precipitate. The previously described experiments were settled in triplicate and performed twice. Drought tolerance was assessed by growth in a medium with reduced water activity $\left(A_{w}\right)$. Each isolate was spread on $10 \%$ TSA medium supplemented with sorbitol at different concentrations: 285, 405, 520 and $780 \mathrm{~g}$ $\mathrm{L}^{-1}$, producing $\mathrm{A}_{w}$ values corresponding to $0.963,0.93,0.912$ and 0.837 , respectively. The plates were incubated at $30 \circ \mathrm{C}$ for $48 \mathrm{~h}$. Salinity tolerance was tested by plating the isolates on nutrient agar (NA) supplemented with $0,2.5,5.0$ and $10 \%$ of $\mathrm{NaCl}$. The plates were incubated at $28{ }^{\circ} \mathrm{C}$ and after $48 \mathrm{~h}$ were assessed for bacterial growth. Tolerance to high temperatures was evaluated by incubating NA plates containing each isolate at $28^{\circ} \mathrm{C}$ (control), $37^{\circ} \mathrm{C}, 42^{\circ} \mathrm{C}$ and $50^{\circ} \mathrm{C}$.

\section{Physiological characterization}

Acetylene Reduction Assay (ARA) - All bacterial isolates were transferred to $10 \mathrm{~mL}$ test tubes containing $4 \mathrm{~mL}$ of semisolid nitrogen-free medium and were incubated during $72 \mathrm{~h}$ at 28 ㄷ. Ten percent of the gas phase in the tested tubes was replaced with acetylene and isolates were incubated for 48 $h$ at $30 \stackrel{\circ}{ }$. The gas phase $(0.1 \mathrm{~mL})$ was analyzed for ethylene production using a Porapak-N 80/100 - INOX column with a gas chromatograph (Shimadzu GC-14A) (Thuler et al., 2003). The assays were performed in triplicate.

ACC Deaminase - Each isolate was grown during 4 days at $28{ }^{\circ} \mathrm{C}$ on minimal medium containing 1-aminocyclopropane1carboxylate (ACC) as the sole carbon source (Glick, 1995). Bacterial growth in this medium indicates ACC deaminase activity.

Production of siderophores - Each isolate was grown in TSB medium at $28{ }^{\circ} \mathrm{C}$ for $24 \mathrm{~h}$ under stirring at $180 \mathrm{rpm}$. Following this incubation period, chrome-azurol sulphonate agar plates were inoculated with five $\mu \mathrm{L}$ of suspension $\left(10^{9}\right.$ cells $\left.\mathrm{mL}^{-1}\right)$ of each isolate tested and incubated during $48-72 \mathrm{~h}$ at 28 ${ }^{\circ} \mathrm{C}$ as described by Louden et al. (2011). An orange-yellow zone around the bacterial colonies confirmed siderophore production. Strains of Staphylococcus aureus ATCC 43300 and Escherichia coli ATCC 25922 were used as negative and positive controls, respectively.

Production of indolic compounds - Each bacterial isolate was inoculated in TSB medium supplemented with $5 \mathrm{mM}$ L-tryptophan and incubated for $72 \mathrm{~h}$ at $28^{\circ} \mathrm{C}$ shaking at 180 rpm. The supernatant was separated by centrifugation and used to determine the content of indole compounds by the Salkowski's assay as described by Gordon \& Weber (1951). For color development, the mixtures were kept in the dark at room temperature for $30 \mathrm{~min}$. The amount of indole compounds was previously estimated with the aid of a standard curve using pure $\operatorname{IAA}\left(0,5,10,15,20,25 \mu \mathrm{g} \mathrm{m}^{-1}\right)$.

Inorganic phosphate solubilization - Cell suspensions of each isolate were transferred to the medium GL containing a calcium phosphate precipitate produced by adding $0.57 \mathrm{M}$ $\mathrm{K}_{2} \mathrm{HPO}_{4}$ and $0.90 \mathrm{M} \mathrm{CaCl}_{2}$ at $\mathrm{pH} 6.5$ (Sylvester-Bradley et al., 1982 ) and incubated for 10 days at $28 \pm 2{ }^{\circ} \mathrm{C}$. The development of a clear zone around the colonies was considered as a positive reaction for phosphate solubilization. Bacillus megaterium ATCC 19213 was used as a positive control.

Statistical Analysis - All samples were evaluated in triplicate and the data were analyzed by variance analysis (ANOVA) and the Scott-Knott's test at $5 \%$ probability was used to compare the means using the statistical software SAS (SAS Institute).

\section{Plant growth promotion potential}

Two experiments were performed in order to check the potential for plant growth promotion by the isolates. The first 
one was set up in vitro to evaluate the ability of the isolates to promote plant growth on a saline environment. For this purpose, cucumber (Cucumis sativus) seeds were surface sterilized by immersion in $70 \%$ ethanol for 2 minutes, and with $1 \%$ sodium hypochlorite for $5 \mathrm{~min}$ followed by three successive rinses with sterile distilled water. In order to test seed germination under salt stress, two surface-sterilized seeds were placed in tubes containing $0.8 \%$ water-agar with $0,30,60,90,120$ and $150 \mathrm{mM} \mathrm{NaCl}$ and incubated at $30^{\circ} \mathrm{C}$ for 5 days. The concentrations 60 and $90 \mathrm{mM} \mathrm{NaCl}$ were selected to evaluate seedling growth, since they had deleterious effects on the rate of germination and development of the plants. Based on preliminary results (data not shown), seven rhizospheric isolates (S1.2, S1.4, S1.5, S1.9, S3.5, S3.6 and S5.1) were selected for this experiment. The growth of cucumber seedlings in the presence and absence of bacteria was evaluated in tubes containing $0.8 \%$ water-agar with 60 and $90 \mathrm{mM} \mathrm{NaCl}$ and incubated at $30{ }^{\circ} \mathrm{C}$. Surface-sterilized seeds were inoculated with bacterial suspensions containing $10^{9}$ cells $\mathrm{mL}^{-1}$. The control was inoculated with sterile distilled water. Growth was evaluated after seven days. The experiment was set up in a random design, and carried out using ten replicates with each tube containing at least two seeds. The second experiment was set up in a greenhouse aiming to test the potential of the isolates in promoting maize (Zea mays L.) plants growth when facing the soil bacterial community. The isolates S1.2, S1.4, S1.5, S1.9, S3.5, S3.6 and S5.1 were grown in TSB medium at $28{ }^{\circ} \mathrm{C}$ for $24 \mathrm{~h}$ under shaking at $150 \mathrm{rpm}$. Cell suspensions containing $10^{9}$ cells $\mathrm{mL}^{-1}$ were prepared with sterile distilled water and $0.1 \%$ xanthan gum for increasing bacterial adherence to seeds. Surface sterilized seeds were immersed in the bacterial suspensions during $2 \mathrm{~h}$. A control was established by immersing disinfested seeds in sterile water containing xanthan gum (0.1\%). After inoculation, seeds were placed in plastic pots containing $3 \mathrm{~kg}$ of soil. Plants were grown in a greenhouse for 45 days. The experimental design was entirely randomized with ten replicates and one plant per pot. The parameters used for evaluation of growth promotion were root length, stem height and shoots and roots dry matter. For both experiments, data were submitted to variance analysis (ANOVA) and the Scott-Knott test at 5\% probability was used to compare the means using the SAS statistical software (SAS Institute).

\section{Results and Discussion}

The presence of nitrogen-fixing bacteria was detected in all internal tissues of the plant (root, stem, leaf, stalk and bulbils) and in the rhizosphere ranging from 2.58 to $3.65 \log _{10}$ number of bacteria $\mathrm{g}^{-1}$ wet weight (Figure 1 ). The highest densities of nitrogen-fixing bacteria were found in rhizosphere, roots and stems; lower densities were found in leaves, stalks and bulbils (Figure 1).

In this study, diazotrophic bacteria associated with Agave sisalana were found to occur at higher densities in rhizospheric soil, inside roots and stems. The organisms were found at

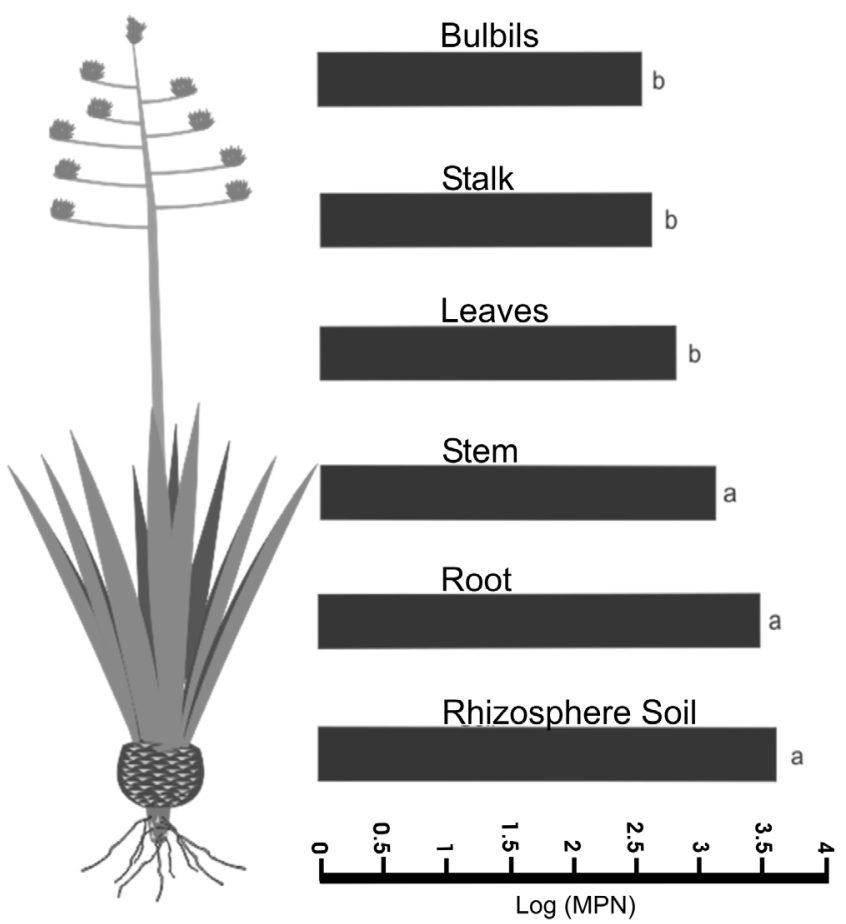

Means followed by the same letter are not significantly different by the Scott-Knott test $(p<0.05)$. Values represent the average of five evaluated plants.

Figure 1. Most probable number (MPN) of endophytic diazotrophs $\left(\log _{10}\right)$ associated with different sisal compartments.

lower densities inside stalks, leaves and bulbils. A total of 191 isolates were obtained from the analyzed samples. These isolates were selected according to morphological patterns exhibited by the colonies. Leaves, rhizospheric soil and bulbils were the samples that presented the highest amount of morphologically distinct colonies, representing the highest amounts of selected isolates, $24.5 \%, 24.0 \%$ and $16.4 \%$, respectively. The remaining $35.2 \%$ were isolated from other parts of the plants.

The nifH trial of the 191 isolates resulted in 176 positive isolates for the presence of the nifH gene. Those isolates that exhibited negative results for the presence of nifH were obtained from leaves and bulbils. BOX-PCR analysis from the 176 nifH-positive isolates generated 45 genomic profiles. One isolate of each genomic profile was selected for further molecular and physiological characterization.

Three phyla and eleven genera were identified among the 176 nifH-positive isolates (Table 1). The phylum Firmicutes was the most abundant, followed by Proteobacteria and Actinobacteria and the genus Bacillus was the most common, followed by Leifsonia, Enterobacter and Rhizobium. Most of the isolates from leaves and bulbils were Bacillus, whereas Enterobacter was the most common genus in stems and stalks, Rhizobium was predominant in roots, and Leifsonia was the most common and was only observed in the soil (Figure 2 and Table 1).

The predominant phylum associated with sisal was the Proteobacteria, also found in other studies with plants of Asparagaceae family (Santos et al., 2014; Desgarannes et al., 


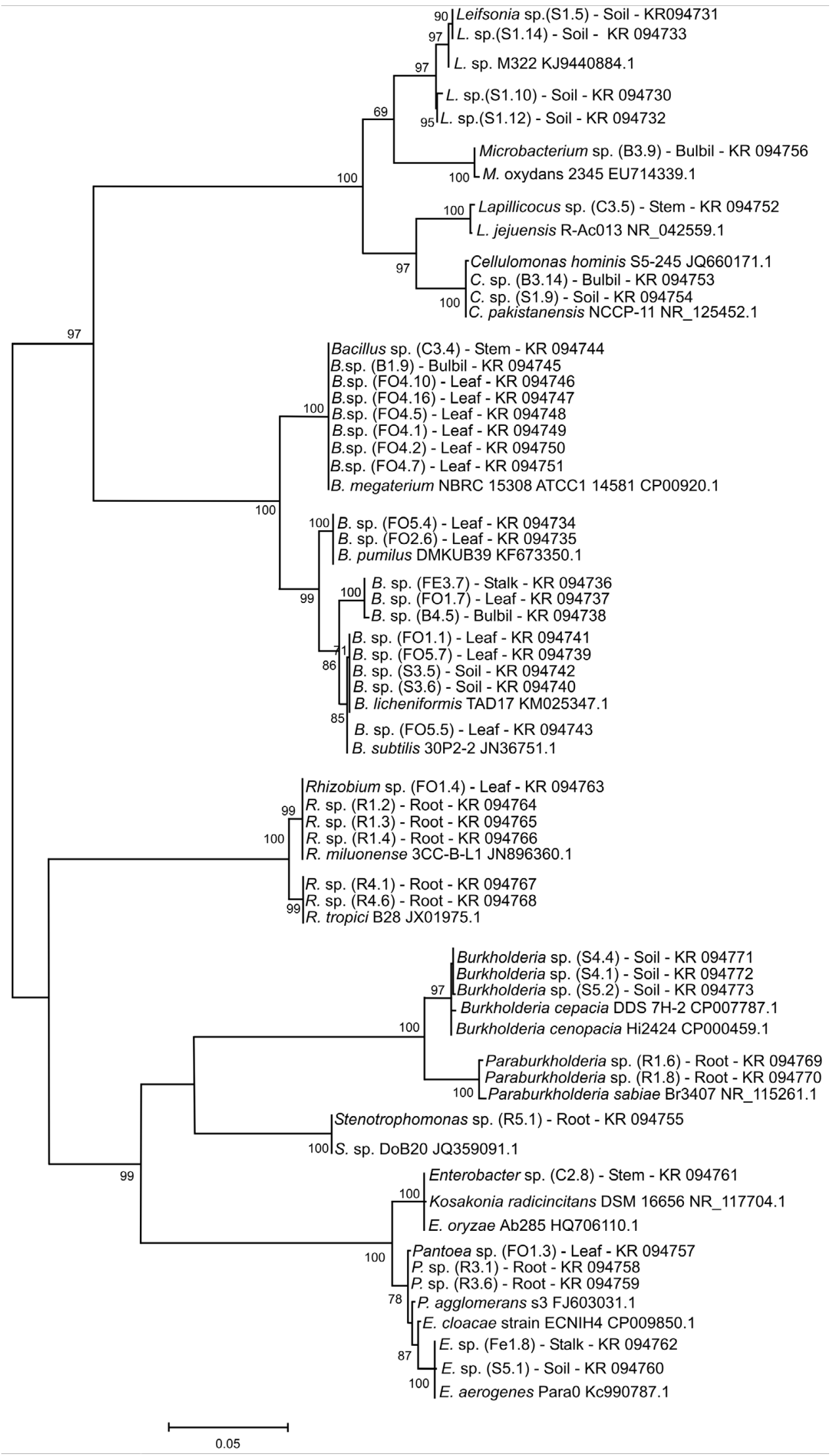

Figure 2. 16S rRNA phylogenetic tree of diazotrophic bacteria associated with sisal compartments (rhizosphere soil, roots, stem, leaves, stalk, and bulbils). The tree was generated with 1407-bp aligned nucleotides by using the maximum likelihood method and the substitution model T92+G. Bootstrap values higher than $70 \%$ are shown on the appropriate branching nodes and were computed with 1,000 resampling. Sequences obtained from public databases for comparison purposes are shown in bold. The scale indicates the number of substitutions per site. 
Table 1. Number of nifH-containing bacterial isolates classified in genera and phyla from soil and sisal tissues.

\begin{tabular}{|c|c|c|c|c|c|c|c|c|}
\hline Phylum & Genus & Soil & Roots & Stems & Leaves & Stalks & Bulbils & Total \\
\hline Firmicutes & Bacillus & 8 & & 7 & 34 & 8 & 20 & 77 \\
\hline \multirow[t]{4}{*}{ Actinobacteria } & Cellulomonas & 1 & & & & & 9 & 10 \\
\hline & Leifsonia & 24 & & & & & & 24 \\
\hline & Lapillicoccus & & & 1 & & & & 1 \\
\hline & Microbacterium & & & & & & 1 & 1 \\
\hline Proteobacteria (Alpha) & Rhizobium & & 11 & & 2 & & & 13 \\
\hline \multirow[t]{2}{*}{ Proteobacteria (Beta) } & Burkholderia & 8 & 1 & & & & & 9 \\
\hline & Paraburkholderia & & 2 & & & & & 2 \\
\hline \multirow[t]{3}{*}{ Proteobacteria (Gamma) } & Enterobacter & 1 & & 8 & & 15 & & 24 \\
\hline & Stenotrophomonas & & 7 & & & & & 7 \\
\hline & Pantoea & & 7 & & 1 & & & 8 \\
\hline Total & & 42 & 28 & 16 & 37 & 23 & 30 & 176 \\
\hline
\end{tabular}

2014). Although there is a great diversity of bacteria associated with plants, the predominant phyla usually are restricted to Actinobacteria, Bacteroidetes, Firmicutes and Proteobacteria, and these are found in the rhizosphere, endosphere, and phylosphere of different plant species (Beckers et al., 2017; Correa-Galeote et al., 2018).

Only the phylum Bacteroidetes was not found in our study (Table 1). Since our objective was not performing an exhaustive survey but rather screening bacterial isolates with specific traits, we could be omitting Bacteroidetes strains in our study.

The distribution of bacterial genera in different plant tissues may be a reflex of the adaptation of these microorganisms to different microhabitats. A recent study has shown that factors as plant tissue and geographical distribution are determinants in the microbiome composition in Agave species (ColemanDerr et al., 2016).

Bacillus was the predominant genus and it was mainly present in the aerial parts of sisal plants. Some isolates were also found in the rhizosphere. Therefore, the biochemical and physiological characteristics of Bacillus (e.g. endospore forming bacteria) can promote its survival in environments under stress conditions (Wang et al., 2014). It is important to verify the systemic distribution of Bacillus in sisal since endophytic Bacillus species can influence plant growth promotion, tolerance to water deficiency, and crop protection against diseases (Ribeiro et al., 2018; Vigani et al., 2018). Isolated with the same genetic pattern, later identified as Enterobacter sp. (Fe1.8), were found endophytically in the roots, stem, stalk and bulb of sisal, indicating their systemic distribution. The distribution pattern of these bacterial groups, as well as their physiological characteristics, can contribute to the maintenance of crops that are not adequately managed, as well as sisal.

Among all the bacterial genera found in this study, only Actinobacteria, Cellulomonas and Lapillicoccus have not been previously reported as atmospheric nitrogen-fixing bacteria. Furthermore, their capacity to fix nitrogen was confirmed by nifH gene presence and their positive reaction in the acetylene reduction assay.

Rhizobium species in association with leguminous plants constitute the classical model for bacterial nitrogen fixation. In this system, atmospheric nitrogen fixation only occurs when the bacteria is in symbiosis. However, it is well established in the literature that Rhizobium and other bacterial genera are able to fix nitrogen out of the classical symbiosis model in non-leguminous plant species (Rouws et al., 2014). Other mechanisms of nitrogen supply were recently demonstrated, in which endophytic bacteria act as a nutrient reservoir, including nitrogen. This mechanism has been observed in Agave tequilana with Bacillus tequilensis, where tests for hydrogen peroxide showed its presence during bacteria degradation in plant tissues, supporting the involvement of reactive oxygen in the degradation process and nitrogen becomes available (Beltran-Garcia et al., 2014). The presence of the nifH gene and ARA activity indicate that bacteria containing these traits are able to fix nitrogen in sisal tissues. Likely the nitrogen is supplied to sisal plants by both mechanisms: bacterial fixation and bacterial degradation by the plant.

Among the 44 isolates used in these in vitro screening assays, the most tolerant to abiotic stress were Pantoea and Bacillus. In contrast, representatives of the phylum Actinobacteria, with the exception of Microbacterium, were not tolerant to reduced water activity (Table 2). All isolates grew on $10 \%$ TSA medium without sorbitol $\left(A_{w} 0.998\right)$, but none were able to grow on medium with $780 \mathrm{~g} \mathrm{~L}^{-1}$ of sorbitol $\left(0.837 \mathrm{~A}_{w}\right)$ (Table 2). Most isolates (86\%) were able to grow on medium with high salt concentration, with exception of some isolates of Paraburkholderia, Leifsonia and Rhizobium (Table

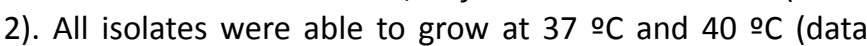
not shown). Isolates of Bacillus, Leifsonia, Burkholderia and Pantoea grew at $50^{\circ} \mathrm{C}$ (Table 2), but Bacillus was the genus with highest tolerance to high temperatures. Production of EPS was observed in $81.8 \%$ of the isolates in medium supplemented with $10 \%$ glucose.

Eight traits supposedly associated with plant growthpromotion were included in this in vitro screening and only indole compounds (AUX) were produced by all 44 isolates tested (Table 3 ). The concentration of indole compounds ranged from 0.09 to $5.56 \mu \mathrm{g} \mathrm{mL}-1$. Overall, $78 \%$ of the isolates produced $<1 \mu \mathrm{g} \mathrm{mL} \mathrm{mL}^{-1}$. Nitrogenase activity measured via acetylene reduction was positive for 34 (77\%) out of 44 tested isolates (Table 3), even though all isolates included 
Table 2. Isolates with potential stress tolerance traits among $44 \mathrm{nifH}$-containing representative isolates defined using BOX-PCR fingerprinting. The table does not show the $37^{\circ} \mathrm{C}$ test, since all 44 isolates were able to grow at this temperature.

\begin{tabular}{lccccccccccc}
\hline & $\begin{array}{c}\mathbf{N} \mathbf{0} \\
\text { isolates }\end{array}$ & $\begin{array}{c}\mathbf{0 . 9 9 5} \\
\mathbf{A}_{\mathbf{w}}\end{array}$ & $\begin{array}{c}\mathbf{0 . 9 6 3} \\
\mathbf{A}_{\mathbf{w}}\end{array}$ & $\begin{array}{c}\mathbf{0 . 9 1 2} \\
\mathbf{A}_{\mathbf{w}}\end{array}$ & $\begin{array}{c}\mathbf{0 . 8 5 9} \\
\mathbf{A}_{\mathbf{w}}\end{array}$ & $\begin{array}{c}\mathbf{0} \% \\
\mathbf{N a C l}\end{array}$ & $\begin{array}{c}\mathbf{2 . 5 \%} \\
\mathbf{N a C l}\end{array}$ & $\begin{array}{c}\mathbf{5 \%} \\
\mathbf{N a C l}\end{array}$ & $\begin{array}{c}\mathbf{1 0} \% \\
\mathbf{N a C l}\end{array}$ & $\mathbf{4 2}{ }^{\circ} \mathbf{C}$ & $\mathbf{5 0}{ }^{\circ} \mathbf{C}$ \\
\hline Burkholderia & 3 & 3 & 1 & 0 & 0 & 3 & 3 & 3 & 3 & 2 & 1 \\
Paraburkholderia & 2 & 0 & 0 & 0 & 0 & 2 & 2 & 2 & 0 & 2 & 0 \\
Enterobacter & 3 & 3 & 3 & 0 & 0 & 3 & 3 & 3 & 3 & 3 & 0 \\
Cellulomonas & 2 & 0 & 0 & 0 & 0 & 2 & 2 & 2 & 2 & 1 & 0 \\
Leifsonia & 4 & 0 & 0 & 0 & 0 & 3 & 4 & 3 & 3 & 1 & 1 \\
Rhizobium & 6 & 4 & 2 & 0 & 0 & 6 & 6 & 5 & 5 & 2 & 0 \\
Stenotrophomonas & 1 & 0 & 0 & 0 & 0 & 1 & 1 & 1 & 1 & 1 & 0 \\
Pantoea & 3 & 3 & 3 & 1 & 0 & 3 & 3 & 3 & 3 & 3 & 1 \\
Bacillus & 18 & 18 & 18 & 15 & 0 & 18 & 18 & 18 & 18 & 18 & 16 \\
Lapillicoccus & 1 & 0 & 0 & 0 & 0 & 1 & 1 & 1 & 1 & 0 & 0 \\
Microbacterium & 1 & 1 & 1 & 0 & 0 & 1 & 1 & 1 & 1 & 0 & 0 \\
\hline
\end{tabular}

Table 3. Isolates with putative plant growth promotion traits among 44 nifH-containing representative isolates defined using BOX-PCR fingerprinting. ARA = Acetylene Reduction Assay $; \mathrm{AUX}=$ Auxin production; $\mathrm{EPS}=$ Exopolysaccharide production; $\mathrm{Si}=$ Siderophores; $P S=$ Phosphate solubilization; $A C C=A C C$ deaminase activity.

\begin{tabular}{lccccccc}
\hline & Num of isolates & ARA & AUX & EPS & Si & PS & ACC \\
\hline Burkholderia & 3 & 2 & 3 & 2 & 1 & 3 & 3 \\
Paraburkholderia & 2 & 2 & 2 & 1 & 1 & 0 & 2 \\
Enterobacter & 3 & 2 & 3 & 2 & 1 & 0 & 3 \\
Cellulomonas & 2 & 1 & 2 & 2 & 0 & 0 & 2 \\
Leifsonia & 4 & 4 & 4 & 3 & 2 & 1 & 4 \\
Rhizobium & 6 & 4 & 6 & 5 & 0 & 0 & 2 \\
Stenotrophomonas & 1 & 1 & 1 & 1 & 0 & 0 & 0 \\
Pantoea & 3 & 2 & 3 & 3 & 1 & 0 & 3 \\
Bacillus & 18 & 15 & 18 & 15 & 4 & 3 & 18 \\
Lapillicoccus & 1 & 0 & 1 & 1 & 0 & 0 & 1 \\
Microbacterium & 1 & 1 & 1 & 1 & 0 & 0 & 1 \\
\hline
\end{tabular}

the nifH gene. Inorganic phosphate solubilization activity was observed in $15.9 \%$ of the 44 tested isolates (Table 3 ). Phosphate solubilization indices ranged from 1.4 to 1.8 (Table S2- supplementary material). Twenty-four (82\%) of the 44 tested isolates were siderophores and ACC deaminase producers (Table 3 ). The highest number of siderophore producers was observed in isolates from the rhizosphere soil. ACC deaminase activity was frequently observed, but some Stenotrophomonas, Bacillus and Rhizobium isolates were not able to produce ACC deaminase in detectable levels (Table 3).
Preliminary experiments carried out with salt concentrations of 30,60 , and $150 \mathrm{mM}$ of $\mathrm{NaCl}$ showed that cucumber seed germination was approximately $88 \%$ for the first two concentrations and $25 \%$ for the highest tested concentration. In further experiments, cucumber seedlings were exposed to concentrations of 60 and $90 \mathrm{mM}$ of $\mathrm{NaCl}$ and treated with seven selected bacterial isolates (Table 4). The salt stress had more dramatic effect on root length than on stem length. Only Leifsonia sp. S1.5 significantly increased cucumber root length (64.5\%) when compared to the positive control at $60 \mathrm{mM} \mathrm{NaCl}$, with no effect of any bacterial isolate at

Table 4. Negative control (C-) - treatment without $\mathrm{NaCl}$, Positive Control $(\mathrm{C}+)$ - treatment with $\mathrm{NaCl}$, Root length (RL), shoot length (SL) and total fresh weight (TFW) of cucumber seedlings treated with seven selected diazotrophic bacteria and exposed to two salt concentrations. Means with the same letter in a column are not significantly different by Scott-Knott's test $(p \geq 0.05)$.

\begin{tabular}{|c|c|c|c|c|c|c|}
\hline \multirow{2}{*}{ Treatments } & \multicolumn{3}{|c|}{$60 \mathrm{mM}(\mathrm{NaCl})$} & \multicolumn{3}{|c|}{$90 \mathrm{mM}(\mathrm{NaCl})$} \\
\hline & $\mathrm{RL}(\mathrm{cm})$ & $\mathrm{SL}(\mathrm{cm})$ & TFW (g) & $\mathrm{RL}(\mathrm{cm})$ & $\mathrm{SL}(\mathrm{cm})$ & TFW (g) \\
\hline$C-$ & $8.05 \mathrm{a}$ & $4.85 a$ & $0.27 a$ & $8.05 \mathrm{a}$ & $4.85 a$ & $0.27 \mathrm{a}$ \\
\hline $\mathrm{C}+$ & $4.60 \mathrm{~b}$ & $4.25 \mathrm{a}$ & $0.15 b$ & $3.05 b$ & $3.30 \mathrm{~b}$ & $0.08 \mathrm{c}$ \\
\hline Leifsonia sp. (S1.4) & $5.87 \mathrm{~b}$ & $6.60 \mathrm{~b}$ & $0.27 a$ & $2.85 \mathrm{~b}$ & $3.30 \mathrm{~b}$ & $0.19 b$ \\
\hline Leifsonia sp. (S1.5) & $7.57 \mathrm{a}$ & $7.35 \mathrm{~b}$ & $0.27 \mathrm{a}$ & $3.30 \mathrm{~b}$ & $2.20 \mathrm{~b}$ & $0.11 \mathrm{c}$ \\
\hline Cellulomonas sp. (S1.9) & $5.02 b$ & $5.60 \mathrm{~b}$ & $0.25 a$ & $0.98 \mathrm{~b}$ & $3.45 b$ & $0.12 c$ \\
\hline Bacillus sp. (S3.6) & $5.30 \mathrm{~b}$ & $5.90 \mathrm{~b}$ & $0.19 \mathrm{~b}$ & $3.34 \mathrm{~b}$ & $3.30 \mathrm{~b}$ & $0.12 \mathrm{c}$ \\
\hline Enterobacter sp. (S5.1) & $6.65 b$ & $6.25 b$ & $0.28 a$ & $2.90 \mathrm{~b}$ & $3.30 \mathrm{~b}$ & $0.17 \mathrm{~b}$ \\
\hline CV\% & 22 & 27 & 19 & 28 & 28 & 32 \\
\hline
\end{tabular}


$90 \mathrm{mM} \mathrm{NaCl}$. For stem length, all isolates were able to reduce the negative effects at $60 \mathrm{mM} \mathrm{NaCl}$ and only the isolate $\mathrm{S} 3.5$ of Bacillus reduced it at $90 \mathrm{mM} \mathrm{NaCl}$. The total fresh weight was similar when compared to the untreated control in all tested isolates, except for two Bacillus at $60 \mathrm{mM} \mathrm{NaCl}$. At $90 \mathrm{mM}$ $\mathrm{NaCl}$, three isolates, two of Leifsonia sp. (S1.2 and S1.4) and one of Enterobacter sp (S5.1), were able to reduce the stress on cucumber seedlings (Table 4).

Although salinity negatively affects all stages of the plant growth by interfering in biochemical and physiological aspects, seed germination and seedling growth are the most sensitive stages (Parihar et al., 2015). Until this date, there is any report in the published literature pointing a member of the genus Leifsonia with ability to reduce negative effects of salinity in plants.

Most bacterial genera tested in our study showed the capacity to promote plant growth and reduce in vivo salt stress, corroborating with the presence of several traits putatively involved in stress tolerance and in vitro growth promotion. Bacteria with these traits can promote plant growth and reduce the deleterious effects of high salt concentrations (Naili et al., 2018). In the present study, it was not provided information regarding all mechanisms present in each isolate. Further studies should focus on the development of biotechnological products with these isolates for the lowinput family-based farmers of the semi-arid region.
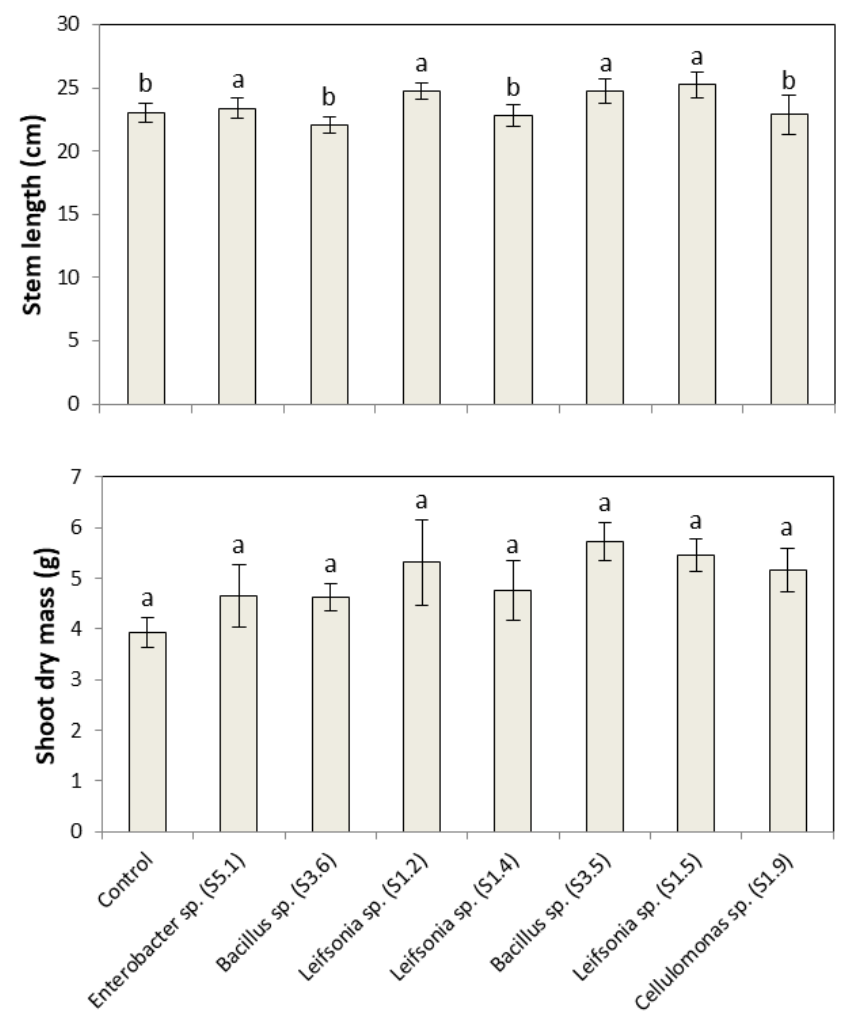

Growth of maize plants was evaluated after the inoculation with same seven selected isolates (S1.2, S1.4, S1.5, S1.9, S3.5, S3.6 and S5.1). Stem length increased significantly in four isolates (Leifsonia sp. (S1.5), Leifsonia sp. (S1.2), Bacillus sp. (S3.5), Leifsonia sp. (S1.5)), and almost all isolates promoted root length (Figure 3). The increases in stem length varied from $7-10 \%$ and in root length from $32 \%$ to $58 \%$. There were no significant differences in the shoot and root dry matter of inoculated plants when compared to the non-inoculated control plants.

Bacteria with different characteristics for plant growth promotion were isolated and selected. When cucumber seeds were inoculated, these isolates promoted significant increases in the stem and root length (Figure 3). The length and architecture enable roots to have better access to water and nutrients, factors that are limiting to plant growth due to the advantage over plants with smaller root system. The shoot and root growth could be associated with bacterial production of hormones or action on humic acids which cause the elongation of cells in the meristem by vacuolar turgor and would not cause significant effects on dry matter (Conceição et al., 2008). In plants under water deficit, a larger root system can promote a higher survival rate.

The fact that sisal is associated with a microbial community, with such physiological versatility that may affect its physiology; may explain, in part, how this crop has been cultivated for several decades without any input of soil fertilizers in the semi-arid region of Bahia state in Brazil.
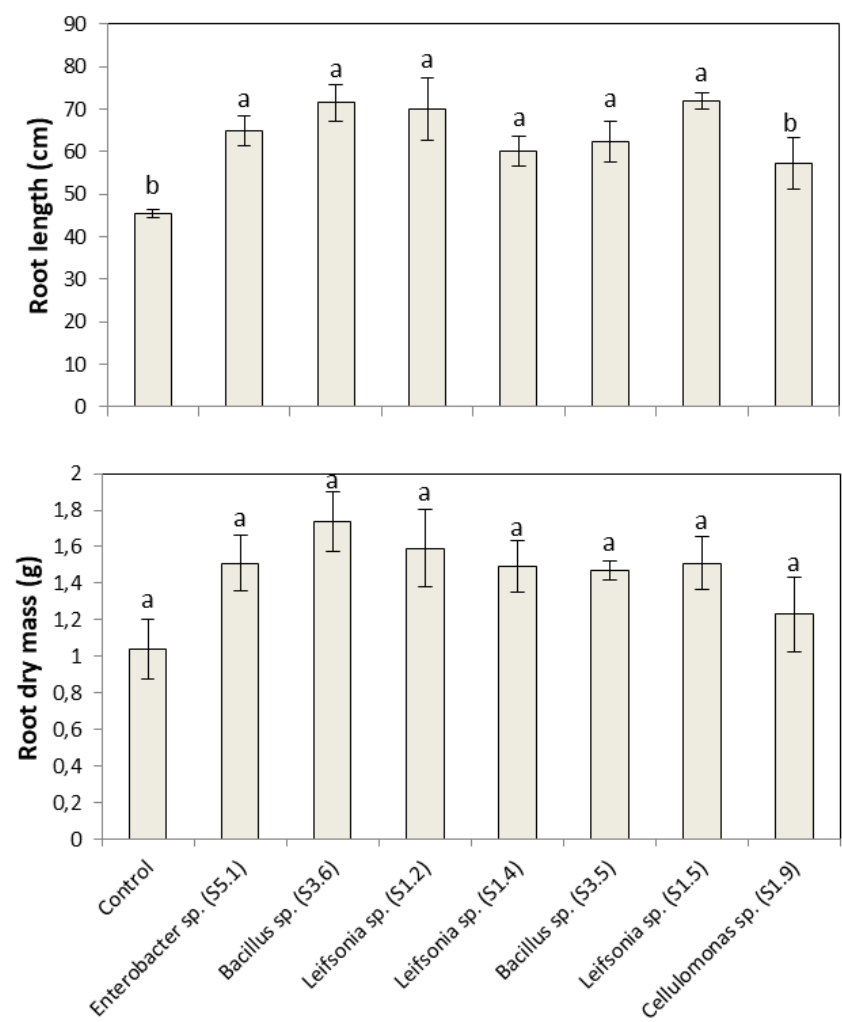

Figure 3. Stem length (SL), root length (RL), shoot dry matter (SDM), root dry matter (RDM) of maize seedlings after treatment with seven diazotrophic isolates. Evaluations were performed at 45 days after seed inoculation and sowing. Error bars indicate standard deviation based on ten replicates of plants grown. Different letters indicate difference between treatments according to Scott-Knott's test $(p<0.05)$. 


\section{Conclusions}

This study has shown that sisal plants host several diazotrophic bacteria that hold mechanisms other than nitrogen fixation that may be involved in plant growth promotion and tolerance to abiotic stress. These bacteria have the potential to be developed into biostimulants for sisal and other crops grown in semi-arid regions.

\section{Acknowledgment}

This study was supported by the Brazilian National Council for Scientific and Technological Development (CNPq) (Process 409309/2016-8).

\section{Literature Cited}

Ali, S. k. Z.; Sandhya, V.; Grover, M.; Kishore, N.; Rao, L. V.; Venkateswarlu, B. Pseudomonas sp. strain AKM-P6 enhances tolerance of sorghum seedlings to elevated temperatures. Biology and Fertility Soil, v.46, n. 1, p.45-55, 2009. https://doi. org/10.1007/s00374-009-0404-9.

Altschul, S. F.; Gish, W.; Miller, W.; Myers, E. W.; Lipman, D. J. Basic local alignment search tool. Journal of Molecular Biology, v. 215 , n. 3, p. 403-410, 1990. https://doi.org/10.1016/S00222836(05)80360-2.

Beckers, B.; De Beeck, M. O.; Weyens, N.; Boerjan, W.; Vangronsveld, J. Structural variability and niche differentiation in the rhizosphere and endosphere bacterial microbiome of field-grown poplar trees. Microbiome, v. 5, n. 25, p.1-17, 2017. https://doi. org/10.1186/s40168-017-0241-2.

Beltran-Garcia, M. J.; White Jr, J.F.; Prado, F. M.; Prieto, K. R.; Yamaguchi, L. F.; Torres, M. S.; Kato, M. J.; Medeiros, M. H. G.; Di Mascio, P. Nitrogen acquisition in Agave tequilana from degradation of endophytic bacteria. Nature, v.4, n. 66938, p.1-7, 2014. https://doi.org/10.1038/srep06938.

Coleman-Derr, D.; Desgarennes, D.; Fonseca-Garcia, C.; Gross, S.; Clingenpeell, S.; Woyke, T.; North, G.; Visell, A.; Partida-Martinez, L. P.; Tringe, S. G. Plant compartment and biogeography affect microbiome composition in cultivated and native Agave species. New Phytologist, v. 209, n.2, p. 798-811, 2016. https://doi. org/10.1111/nph.13697.

Conceição, P. M.; Vieira, H. D.; Canellas, L. P.; Marques Junior, R. B.; Olivares, F. L. Recobrimento de sementes de milho com ácidos húmicos e bactérias diazotróficas endofíticas. Pesquisa Agropecuária Brasileira, v. 43, n.4, p.545-548, 2008. https://doi. org/10.1590/S0100-204X2008000400015.

Correa-Galeote, D.; Bedmar, E. J.; Arone, G. J. Maize endophytic bacterial diversity as affected by soil cultivation history. Frontier in Microbiology, v. 9, p.1-9, 2018. https://doi.org/10.3389/ fmicb.2018.00484.

Desgarennes, D.; Garrido, E.; Torres-Gomez, M. J.; Peña-Cabriales, J. J.; Partida-Martinexz, L. P. Diazotrophic potential among bacterial communities associated with wild and cultivated Agave species. FEMS Microbiol Ecology, v. 90, n. 3, p.8455-57, 2014. https://doi. org/10.1111/1574-6941.12438.
Gamalero, E.; Glick, B. R. Bacterial Modulation of Plant Ethylene Levels. Plant Physiology, v. 169, p. 13-22, 2015. https://doi. org/10.1104/pp.15.00284.

Glick, B. R. The enhancement of plant growth by free-living bacteria. Canadian Journa of Microbiology, v.41, n. 2, p.109-117, 1995. https://doi.org/10.1139/m95-015.

Gordon, S. A.; Weber, R. P. Colorimetric estimation of indol acetic acid. Plant Physiology, v. 26, n. 4, p.192-195, 1951. https://doi. org/10.1104/pp.26.1.192.

Guimarães, D. P.; Costa, F.; Rodrigues, M. J.; Maugeri, F. Optimization of dextran syntesis and acidic hydrolisis by surface response analysis. Brazilian Journal of Chemical Engineering, v. 16 n. 2, p.129-139, 1999. https://doi.org/10.1590/S0104 66321999000200004

Instituto Brasileiro de Geografia e Estatística - IBGE. Sistema IBGE de Recuperação Automática - SIDRA. Produção agrícola municipal. 2017. https://sidra.ibge.gov.br/tabela/1613\#notas-tabela. 15 Jan. 2019

Legendre, L.; Legendre, P. Numerical ecology. New York: Elsevier, 1983. 420p

Lima, J. V. L; Weber, O. B.; Correia, D.; Soares, M. A.; Senabio, J. A. Endophytic bacteria in cacti native to a Brazilian semi-arid region. Plant and Soil, v. 389, n. 1-2, p.25-33, 2015. https://doi. org/10.1007/s11104-014-2344-x.

Louden, B. C.; Haarmann, D.; Lynne, A. M. Use of blue Agar CAS assay for siderophore detection. Journal of Microbiology and Biology Education, v. 12, n. 1, p.51-53, 2011. https://doi.org/10.1128/ jmbe.v12i1.249.

Naili, F.; Neifar, M.; Elhidri, D.; Cherif, H.; Bejaoui, B.; Aroua, M.; Bejaoui, Z.; Abassi, M.; Mguiz, K.; Chouchane, H.; Ouzari, H. I.; Cherif, A. Optimization of the effect of PGPR-based biofertlizer on wheat growth and yield. Biometrics \& Biostatistics International Journal, v. 7, n. 3, p.226-232, 2018. https://doi:10.15406/ bbij.2018.07.00213.

Navarro-Torre, S.; Barcia-Piedras, J. M.; Mateos-Naranjo, E.; RedondoGómez, S.; Camacho, M.; Caviedes, M. A.; Pajuelo, E.; RodriguezLlorente, I. D. Assessing the role of endophytic bacteria in the halophyte Arthrocnemum macrostachyum salt tolerance. Plant Biology, v. 19, n. 2, p. 249-256, 2017. https://doi.org/10.1111/ plb.12521.

Naveed, M.; Mitter, B.; Reichenauer, T. G.; Wieczorek, K.; Sessitschi, A. Increased drought stress resilience of maize through endophytic colonization by Burkholderia phytofirmans PsJN Enterobacter sp. FD17. Environmental Experimental Botany, v. 97, p. 30-39, 2014. https://doi.org/10.1016/j.envexpbot.2013.09.014.

Parihar, P.; Singh, S.; Singh, R.; Singh, V. P.; Prasad, S. M. Effect of salinity stress on plants and its tolerance strategies: a review. Environmental Science Pollution Research, v. 22, n. 6, p. 40564075, 2015. https://doi.org/10.1007/s11356-014-3739-1.

Paulo, E. M.; Vasconcelos, M. P.; Oliveira, I. S.; Affe, H. M. J.; Nascimento, R.; Melo, I. S.; Roque, M. R. A.; Assis, A. S. An alternative method for screening lactic acid bacteria for the production of exopolysaccharides with rapid confirmation. Ciência e Tecnologia de Alimentos, v.32, n. 4, p.710-714, 2012 https://doi.org/10.1590/S0101-20612012005000094. 
Queiroz, L. P. Flowering plants of the Brazilan semi-arid. In: Queiroz LP, Rapini A, Giulietti AM, editors. Towards greater knowledge of the Brazilian semi-arid biodiversity. Brasília: Ministério de Ciência e Tecnologia, 2006. Cap. 6, p.45-49.

Ribeiro, V. P.; Marriel, I. E.; Sousa, S. M.; Lanab, U. G. P. Endophytic Bacillus strains enhance pearl millet growth and nutrient uptake under low-P. Brazilian Journal of Microbiology, v. 49, suppl. 1, p. 40-46, 2018. https://doi.org/10.1016/j.bjm.2018.06.005.

Rodal, M. J. N.; Costa, K. C. C.; Silva, A. C. B. L. Local scale variation in plant assemblage's attributes in the semi-arid region, Northeastern Brazil. Journal of Environmental Analysis and Progress, v. 3, n. 4, p. 396-405, 2018. https://doi.org/10.24221/ jeap.3.4.2018.1673.396-405.

Rouws, L. F. M.; Leite, J.; Matos, G. F.; Zilli, J. E.; Coelho, M. R. R.; Xavier, G. R.; Fischer, D.; Hartmann, A.; Reis, V. M.; Baldani, J. I. Endophytic Bradyrhizobium spp. isolates from sugarcane obtained through different culture strategies. Environmental Microbiology Reports, v.6, n. 4, p.354-363, 2014. https://doi. org/10.1111/1758-2229.12122.

Santos, A. F. J.; Martins, C. Y. S.; Santos, P. O.; Corrêa, E. B.; Barbosa, H. R.; Sandoval, A. P. S.; Oliveira, L. M.; Souza, J. T.; Soares, A. C. F. Diazotrophic bacteria associated with sisal (Agave sisalana Perrine ex Engelm): potential for plant growth promotion. Plant and Soil, v. 385, n. 1-2, p.37-48, 2014. https://doi.org/10.1007/ s11104-014-2201-x.

Suinaga, F. A.; Silva, O. R. R. F.; Coutinho, W. M. A história. In: Andrade, W. (Ed.). O sisal do Brasil. 1.ed. Salvador: SINDIFIBRAS; Brasília: APEX-Brasil, 2006. Cap. 3, p. 18-21.

Sylvester-Bradley, R.; Askawa, N.; La Torraca, S.; Magalhães, F. M. N.; Oliveira, L.; Pereira, R. M. Levantamento quantitativo de microrganismos solubilizadores de fosfatos na rizosfera de gramíneas e leguminosas forrageiras na Amazônia. Acta Amazonica, v. 12, n. 1, p.15-22, 1982. https://doi. org/10.1590/1809-43921982121015.
Tamura, K.; Peterson, D.; Peterson, N.; Steche, G.; Nei, M.; Kumar, S. (2011) MEGA5: molecular evolutionary genetics analysis using maximum likelihood, evolutionary distance, and maximum parsimony methods. Molecular Biology and Evolution, v.28, n. 10, p.2731-2739. https://doi-org.ez86.periodicos.capes.gov. $\mathrm{br} / 10.1093 / \mathrm{molbev} / \mathrm{msr} 121$

Thuler, D. S.; Floh, E. I. S.; Handro, W.; Barbosa, H. R. Beijerinckia derxii releases plant growth regulators and amino acids in synthetic media independent of nitrogenase activity. Journal of Applied Microbiology, v.95, n.4, p.799-806, 2003. https://doi. org/10.1046/j.1365-2672.2003.02047.x.

Timmusk, S.; El-Daim, I. A. A.; Copolovi, L.; Tanilas, T.; Kännaste, A.; Behers, L.; Nevo, E.; Seisenbaeva, G.; Stenström, E.; Niinemets, Ü.Drought-tolerance of wheat improved by rhizosphere bacteria from harsh environments: enhanced biomass production and reduced emissions of stress volaties. PLoS ONE, v.9, n. 5, p.1-13. 2014. https://doi.org/10.1371/journal.pone.0096086.

Vigani, G.; Rolli, E.; Marasco, R.; Dell'Orto, M.; Michoud, G.; Soussi, A., Raddadi, N.; Borin, S.; Sorlini, C.; Zocchi, G.; Daffonchio, D. Root bacterial endophytes confer drought resistance and enhance expression and activity of a vacuolar $\mathrm{H}^{+}$-pumping pyrophosphatase in pepper plants. Environmental Microbiology, Epub ahead of print, 2018. https://doi.org/10.1111/14622920.14272.

Wang, S.; Ouyang, L.; Ju, X.; Zhang, L.; Zhang, Q.; Li, Y. Survey of plant drought-resistance promoting bacteria from Populus euphratica tree living in arid area. Indian Journal of Microbiology, v. 54, n. 4, p.419-426, 2014. https://doi.org/10.1007/s12088-014-0479-3.

Weisburg, W. G.; Barns, S. M.; Pelletier, D. A.; Lane, D. J. $16 \mathrm{~S}$ ribosomal DNA amplification for phylogenetic study. Journal of Bacteriology, v. 173, n. 2, p.697-703, 1991. https://doi. org/10.1128/jb.173.2.697-703.1991.

Wilson, P.W.; Knight, S.G. Experiments in bacterial physiology. 3.ed. Minneapolis: Burgess Publishing Co., 1952. 61p. 